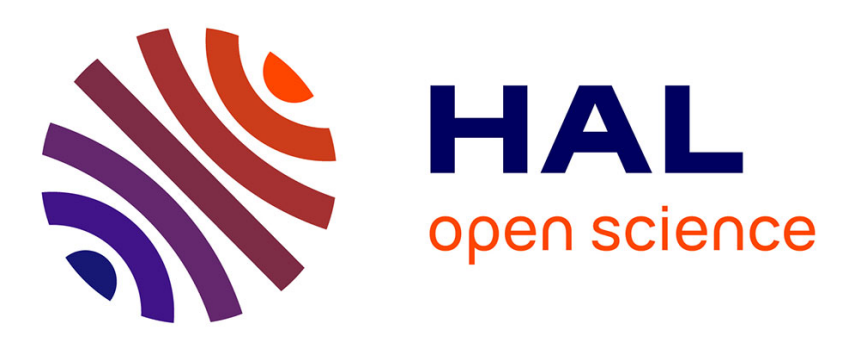

\title{
Hydrophilization by coating of silylated polyoxazoline using sol-gel process
}

Cédric Alexis, Clarence Charnay, Vincent Lapinte, Jean-Jacques Robin

\section{To cite this version:}

Cédric Alexis, Clarence Charnay, Vincent Lapinte, Jean-Jacques Robin. Hydrophilization by coating of silylated polyoxazoline using sol-gel process. Progress in Organic Coatings, 2013, 76, pp.519-524. 10.1016/j.porgcoat.2012.09.012 . hal-00792991

\section{HAL Id: hal-00792991 \\ https://hal.science/hal-00792991}

Submitted on 21 Feb 2013

HAL is a multi-disciplinary open access archive for the deposit and dissemination of scientific research documents, whether they are published or not. The documents may come from teaching and research institutions in France or abroad, or from public or private research centers.
L'archive ouverte pluridisciplinaire HAL, est destinée au dépôt et à la diffusion de documents scientifiques de niveau recherche, publiés ou non, émanant des établissements d'enseignement et de recherche français ou étrangers, des laboratoires publics ou privés. 


\title{
Hydrophilization coating of silylated polyoxazoline using sol-gel process
}

\author{
Cédric Alexis, ${ }^{a, b}$ Clarence Charnay, ${ }^{b}$ Vincent Lapinte ${ }^{\mathrm{a} *}$ and Jean-Jacques Robin ${ }^{\mathrm{a}}$
}

${ }^{a}$ Institut Charles Gerhardt, Montpellier, UMR 5253 CNRS- UM2-ENSCM-UM1. Equipe: Ingénierie et Architectures Macromoléculaires, Université Montpellier 2 - Bât. 17 -CC1702, Place Eugène Bataillon, 34095 Montpellier Cedex 5, France. E-mail:vincent.lapinte@univ-montp2.fr; Fax: +33 04671440 28; Tel: +330467144832.

${ }^{b}$ Institut Charles Gerhardt, Montpellier, UMR 5253 CNRS- UM2-ENSCM-UM1. Equipe: AIME (Agrégats, Interfaces et Matériaux pour l'Energie), Université Montpellier 2 - Bât. 15 - CC15, Place Eugène Bataillon, 34095 Montpellier Cedex 5, France.E-mail:clarence.charnay@univ-montp2.fr 


\begin{abstract}
Hybrid films prepared from TEOS and polyoxazoline cross-linkers( $\mathrm{Si}-\mathrm{POx}-\mathrm{Si}$ ) were coated on different substrates in order to modify their surface properties. The film cohesion and adhesion on substrates were expected through the hydrogen bonding of the polyoxazoline crosslinked network. Low molecular-weight $\alpha, \omega$-unsaturated polyoxazolines (DA-PMOx)s were synthesized by a one step cationic ring-opening polymerization (CROP) of 2-methyl-2-oxazoline (MOx) with a good control over the molecular weight. Based on double thiol-ene coupling (d-TEC), a postfunctionalization of end chains DA-PMOx gave in good yield polyoxazoline cross-linker (SiPOx-Si). Glass and various polymer substrates (PP, PEI, POM...) were spin coated by the organic-inorganic hybrid films through sol-gel process. AFM, SEM, visible reflectance spectroscopy and contact angle experiments allowed the full characterization of targeted surfaces and demonstrated the efficiency of the polyoxazoline coating.
\end{abstract}




\section{Introduction}

Nowadays, sol-gel process was known to be one of the mainly practical methods for substrate coating. Nevertheless, the achievement of crack-free hydrophilic films on organic polymer substrates still reminded challenging. Indeed a main limitation in using coated plastics was the weak interfacial adhesion of the inorganic thin film on the polymeric substrate resulting in cracking upon drying process [1]. In order to prevent this drawback,surface activation methods such as plasma have been developed, to activate the surface and improve the wettability by bonding between the coating and the substrate [2]. Moreover, glycidoxypropyltrimethoxysilane (GOTMS) was used to enhance the properties ofthe deposited film [3]. In this way, our efforts were concentrated on the elaboration of crack-free coating for polymer supports using hybrid solgel technique with a new polyoxazoline based precursor. The modified polyoxazoline acted as hydrophilic cross-linker of the polymeric network where its flexible chains avoided cracks upon drying process.

Over the last few years, polyoxazolines have received significant attention, due to their high potential for applications in technical matters [3,4] and biomedical applications [5-8]. They have allowed the synthesis of a wide range of functionalized polymers [9-12]. Functionalities can be introduced into the polymer through the initiation $[13,14]$ and/or the termination steps [15] giving head and/or end groups. Poly(2-oxazoline)s with methyl (PMOx) and ethyl side groups are water-soluble polymers. These candidates are applied as compatibilizer between reinforcing agent and the polymer matrix in composites [16], biocompatible agent in the fabrication of tip for scanning probe nanolithography [17] and protein-repellent agent in surface coatings [18].

Various hybrid polyoxazoline coatings were already explored with colloidal polymer hybrids where the $\mathrm{C}=\mathrm{O}$ bonds interacted by hydrogen bonds with $\mathrm{Si}-\mathrm{OH}$ of silicate network [2022]. The grafting of PMOx on silicone was another polyoxazoline coating method [23]. Finally 
the sol-gel process between an inorganic cross-linker such as tetraethyl orthosilicate (TEOS) and PMOx bearing an alkoxysilane coupling agent was investigated. The sol-gel reactive group was introduced either in pendant chain of oxazoline monomer [24,25] or in the polyoxazoline endchain [26]. In the latter case, hydrosilylation reaction was used to modify the $\alpha$ - or $\omega$-end group of polyoxazoline [23,27-30]. Nevertheless, this method suffers from low yield.

In this contribution, a new synthetic pathway was investigated to convert by one step process $\alpha, \omega$-allylic PMOx (DA-PMOx) into $\alpha, \omega$-alkoxysilane PMOx (Si-PMOx-Si) through a double thiol-ene coupling (d-TEC). The TEC reaction has been extensively exploited in polymer chemistry [31,32] and in biomaterials for application in medicine, especially dentistry [33], taking advantage of the absence of toxic transition-metal catalyst. However, only few examples of thiol-ene coupling from polyoxazoline were described in the literature [34-38] and never a one step double thiol-ene coupling.

In a second part of the study, this new sol-gel precursor, $\mathrm{Si}-\mathrm{PMOx}-\mathrm{Si}$, was used to achieve an improved crack-free inorganic-organic hybrid coating on raw polymeric substrates through a sol-gel route and a deposition carried out by spin-coating technique. Then, the surface of the coated substrates was observed on SEM images and the roughness was measured by AFM spectroscopy. The modification of the surface was finally evaluated by contact angle measurement as well as the transparency was measured by visible reflectance spectroscopy. 


\section{Experimental section}

\subsection{Materials and chemicals}

Allylic alcohol, tosyl chloride, allylamine, 3-mercaptopropyl-triethoxysilane (TEOSithiol), tetraethyl orthosilicate (TEOS), 3-glycidoxypropyltrimethoxysilane (GOTMS), methanol, ethanol, $\mathrm{H}_{2} \mathrm{SO}_{4}, \mathrm{HCl}$, diethyl ether, $\mathrm{KOH}$ and $\mathrm{CaH}_{2}$ were purchased from ACROS and were used as received. Acetonitrile was dried and distilled according to standard procedures [39]. 2-Methyl2-oxazoline (MOx) was dried, distilled from $\mathrm{CaH}_{2}$ and stored under a dry nitrogen atmosphere. Acetate butyrate cellulose (CAB), Polystyrene (PS), Polyoxomethylene (POM), Polyetherimide (PEI) and Polypropylene (PP) substrates were purchased from Goodfellow and were used as received. Glass substrates (microscope slides from Marienfeld) were carefully washed with a solution of $\mathrm{H}_{2} \mathrm{SO}_{4} / \mathrm{H}_{2} \mathrm{O}_{2}$ and then intensively rinsed with MilliQ water, and dried. Deuterated solvent $\left(\mathrm{CDCl}_{3}\right)$ was purchased from SDS and were used without further purification.

\subsection{Instrumentation and characterization}

${ }^{1} \mathrm{H}$ and ${ }^{13} \mathrm{C}$ NMR spectra were recorded using a Bruker $\mathrm{AC} 200$ with $\mathrm{CDCl}_{3}$ as solvent. In ${ }^{1} \mathrm{H}$ NMR chemical shifts were referenced to the peak of residual $\mathrm{CHCl}_{3}$ at $7.26 \mathrm{ppm}$. In ${ }^{13} \mathrm{C} \mathrm{NMR}$ chemical shifts were referenced to $\mathrm{CDCl}_{3}$ at $77 \mathrm{ppm}$. Size exclusion chromatography (SEC) was performed on a PL-GPC 50 Plus equipped with an RI refractive index detector. Three PL aquagel-OH columns $\left(25,7.5\right.$ and $4.6 \mathrm{~mm}$ ID) were used at $40^{\circ} \mathrm{C}$ with a $0.8 \mathrm{~mL} \cdot \mathrm{min}^{-1}$ flow rate of $\mathrm{H}_{2} \mathrm{O} / \mathrm{CH}_{3} \mathrm{OH}: 7 / 3(0.1 \mathrm{M} \mathrm{LiNO})_{3}$, calibrated using PEO standards.Contact angles were determined with a Digidrop camera contact-angle meter, Fast/60 from GBX, with an automatic liquid dispenser. Experiments were carried out at room temperature. A liquid droplet $(4 \mu \mathrm{L})$ was carefully placed on the sample surface and imaged with a coupling device camera. The contact 
angle was determined mathematically through the fitting of the Young-Laplace equation. The displayed values are the average value of 3 measurements with a dispersion of measured data lesser than $5 \%$.Scanning electron microscopy (SEM) images were obtained on a Hitachi S2600N scanning electron microscope. AFM images were obtained with an AFM Digital D 3100 (Digital Instruments) in tapping mode and phase. Visible reflectance spectroscopy was carried out using a reflectance fiber optic probe FCR-7IR200-2 from Avantes, a tungsten halogen light source (150W) and an AvaSpec-2048TEC spectrometer.

2.3 Preparation of Allylic p-toluene sulfonate (ATs). KOH (15 g, $267 \mathrm{mmol}, 2$ eq) was dissolved in $160 \mathrm{~mL}$ of ethyl ether solution containing allylic alcohol (2.5 eq). At $5^{\circ} \mathrm{C}$,tosyl chloride (25 g, $131 \mathrm{mmol}, 1 \mathrm{eq})$ was added dropwise . The resultingmixture was stirred for $6 \mathrm{~h}$ at room temperature and filtered and finallyconcentrated under pressure. The product ATs was isolated in 89\% yield. ${ }^{1} \mathrm{H}$ NMR $\left(\mathrm{CDCl}_{3}\right) \delta(\mathrm{ppm}): 7.8\left(\mathrm{~d}, 2 \mathrm{H}, \mathrm{H}_{\text {aromatic }}\right), 7.4\left(\mathrm{~d}, 2 \mathrm{H}, \mathrm{H}_{\text {aromatic }}\right), 5.7$ $5.6(\mathrm{~m}, 1 \mathrm{H}, \mathrm{CH}=), 5.3\left(\mathrm{~m}, 2 \mathrm{H}, \mathrm{CH}_{2}=\right), 4.6\left(\mathrm{~d}, 2 \mathrm{H},=\mathrm{CH}-\underline{\mathrm{H}}_{2}-\right), 2.5\left(\mathrm{~s}, 3 \mathrm{H}, \mathrm{CH}_{3}\right) .{ }^{13} \mathrm{C} \mathrm{NMR}$ $\left(\mathrm{CDCl}_{3}\right) \delta(\mathrm{ppm}): 145.0\left(\underline{\mathrm{C}}_{\text {aromatic }}-\mathrm{CH}_{3}\right), 133.2\left(\underline{\mathrm{C}}_{\text {aromatic }}-\mathrm{S}\right), 130.3$ and $127.9\left(\mathrm{CH}_{\text {aromatic }}\right), 120.3$ $\left(\mathrm{CH}_{2}=\right), \mathrm{CH}=$ no visible, $70.9\left(\mathrm{CH}_{2}-\mathrm{O}\right), 21.7\left(\mathrm{CH}_{3}\right)$.

2.4 Typical polymerization of MOx using ATs (DA-PMOx). All reactions were carried out under a dry nitrogen atmosphere. ATs and MOx were dissolved in dry acetonitrile $(4 \mathrm{M})$. The solution was vigorously stirred at $80^{\circ} \mathrm{C}$. The reaction product was quenched by addition of an adequate amount of allylamine (10 eq). The flask was maintained for $24 \mathrm{~h}$ at $50^{\circ} \mathrm{C}$. After cooling, the polymer was isolated by slow precipitation from cold diethyl ether. DA-PMOx was isolated in $93 \%$ yield. ${ }^{1} \mathrm{H}$ NMR $\left(\mathrm{CDCl}_{3}\right) \delta(\mathrm{ppm}): 5.8(\mathrm{~m}, 1 \mathrm{H}, \mathrm{CH}=), 5.2\left(\mathrm{~m}, 2 \mathrm{H}, \mathrm{CH}_{2}=\right), 3.9-3.3(\mathrm{~m}, 4 \mathrm{nH}$, $\mathrm{CH}_{2}$ of POx), $2.8\left(\mathrm{~m}, 4 \mathrm{H},=\mathrm{CH}-\underline{\mathrm{H}}_{2}-\mathrm{N}\right), 2.0\left(\mathrm{~s}, 3 \mathrm{nH}, \mathrm{CH}_{3}\right.$ of $\left.\mathrm{POx}\right) .{ }^{13} \mathrm{C} \mathrm{NMR}\left(\mathrm{CDCl}_{3}\right) \delta(\mathrm{ppm})$ : 
171.2-170.6 $(\mathrm{C}=\mathrm{O}$ of POx $), 132.2(\mathrm{CH}=), 118.1-117.1\left(\mathrm{CH}_{2}=\right), 51.1-43.2\left(\mathrm{CH}_{2}-\mathrm{N}\right.$ and $\mathrm{CH}_{2} \mathrm{n}$ of POx), $20.9\left(\mathrm{CH}_{3}\right.$ of POx $)$.

2.5 Typical di-thiol-ene coupling (d-TEC) (Si-PMOx-Si). In a $50 \mathrm{~mL}$ round flask DA-PMOx, TEOSi-thiol ( 3 eq per $\mathrm{C}=\mathrm{C}$ group) and $\mathrm{AIBN}(0.12 \mathrm{eq})$ were dissolved in $\mathrm{CHCl}_{3}$ solution $(0.3 \mathrm{M})$. Nitrogen was bubbled in the solution for $30 \mathrm{~min}$. The reaction mixture was heated at $60^{\circ} \mathrm{C}$ for 72 hours under a nitrogen atmosphere. The reaction mixture was poured in a large excess of cold ethyl ether. Si-PMOx-Si was isolated in $86 \%$ yield after precipitation. ${ }^{1} \mathrm{H} \mathrm{NMR}\left(\mathrm{CDCl}_{3}\right) \delta(\mathrm{ppm})$ : 3.8-3.3 (m, $(4 \mathrm{n}+12) \mathrm{H}, \mathrm{CH}_{2} \mathrm{POx}$ and $\mathrm{CH}_{3}-\mathrm{C}_{2}$ of $\left.\mathrm{OEt}\right), 3.2-2.8\left(\mathrm{~s}, 4 \mathrm{H}, \mathrm{CH}_{2}-\mathrm{N}\right), 2.5\left(\mathrm{~m}, 8 \mathrm{H}, \mathrm{CH}_{2}-\right.$ S), $2.1\left(\mathrm{~s}, 3 \mathrm{nH}, \mathrm{CH}_{3}\right.$ of POx), 1.8-1.6 (m, 8H, $\underline{\mathrm{C}}_{2}-\mathrm{CH}_{2}-\mathrm{Si}$ and $\left.\mathrm{C}_{2}-\mathrm{CH}_{2}-\mathrm{N}\right), 1.2\left(\mathrm{t}, 18 \mathrm{H}, \mathrm{CH}_{2}-\right.$ $\mathrm{C}_{\underline{3}}$ of $\left.\mathrm{OEt}\right), 0.7\left(\mathrm{t}, 4 \mathrm{H}, \mathrm{CH}_{2}-\mathrm{Si}\right) .{ }^{13} \mathrm{C} \mathrm{NMR}\left(\mathrm{CDCl}_{3}\right) \delta(\mathrm{ppm}): 170.1(\mathrm{C}=\mathrm{O}$ of $\mathrm{POx}), 57.8\left(\mathrm{CH}_{2}\right.$ of O-Et), 51.4-42.6 ( $\mathrm{CH}_{2}$ of POx, $\mathrm{CH}_{2}-\mathrm{CH}_{2}-\mathrm{S}$ and $\left.\mathrm{CH}_{2}-\mathrm{N}\right), 34.6\left(\mathrm{CH}_{2}-\mathrm{S}\right.$ side end group), $28.1\left(\mathrm{CH}_{2}-\right.$ S side POx), $20.5\left(\mathrm{CH}_{3}\right.$ of POx $), 17.7\left(\mathrm{CH}_{3}\right.$ of O-Et), $9.3\left(\mathrm{CH}_{2}-\mathrm{Si}\right)$.

2.6 Film elaboration. The reactive polyoxazoline Si-PMOx-Si was co-hydrolyzed and cocondensed with TEOS and GOTMS with $\mathrm{HCl}$ as acidic catalyst to yield a series of hybrid sol-gel sols. The solutions stirred for 2 hours were then spincoated at $1800 \mathrm{rpm}$, for $20 \mathrm{~s}$ on different inorganic or polymer substrates, glass, POM, PS, CAB, PEI and PP. Every coating procedure was performed around $30^{\circ} \mathrm{C}$. In the preparation of the sol, Si-PMOx-Si was first diluted in absolute ethanol to obtain a $10 \mathrm{wt} \%$ solution. The weight ratio between Si-PMOx-Si solution and silica precursors was optimized and the following composition of the hybrid sols 1:0.3:0.2 (Si-PMOxSi:GOTMS:TEOS weight ratio) displayed coated films with no macroscopic defects. 


\section{Results and discussion}

\subsection{Synthesis of polyoxazoline cross-linker}

Hybrid sol-gel coatings were realized from PMOx bearing alkoxysilane end groups, $\mathrm{Si}$ PMOx-Si, as shown in Scheme 1. The previous stage was the synthesis of $\alpha, \omega$-telechelic polyoxazoline DA-PMOx bearing allylic end-groupsobtainedby both the addition of allyl tosylate initiator ATs and allylamine as termination agent.

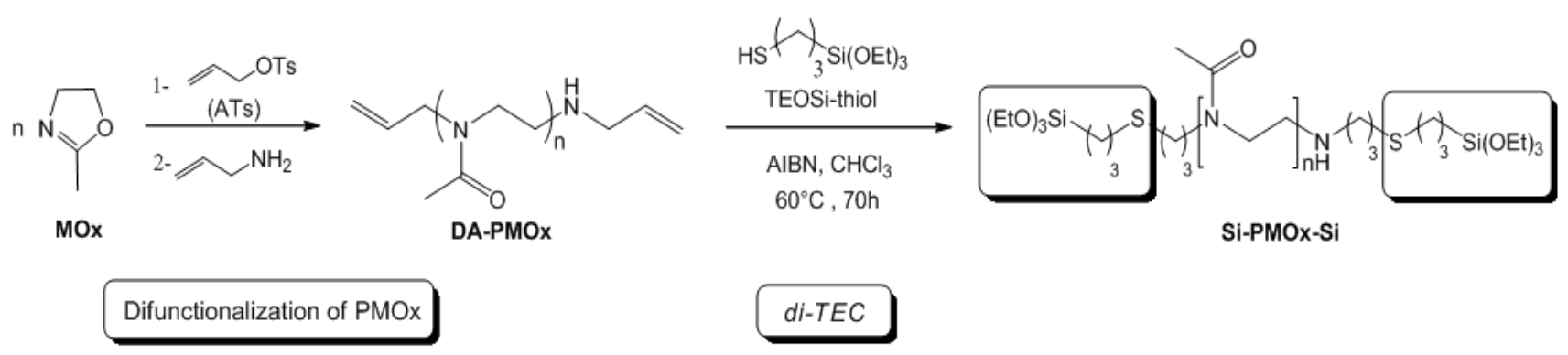

Scheme 1.Synthesis of Si-PMOx-Si.

Low molecular weight polyoxazolines were further used as sol-gel cross-linkers. As a consequence, the control over molecular weight was investigated using SEC and NMR techniques. The experimental number-average molecular weights, Mn,SEC and the theoretical values (calculated from the molar ratio of introduced monomer MOx, DPn,th) versus conversion werereported in Supporting Information. The Mn,SEC values wereslightly higher than the theoretical ones. $\mathrm{M}_{\mathrm{n}, \mathrm{SEC}}$ values increased linearly until approximately $80 \%$ whichindicatedthat the transfer reactions were negligible in this range. Above this limit the decrease of the molecular weight and the enhancement of polydispersity indicated the presence of transfer reactions. In conclusion, $\alpha, \omega$-allylic polyoxazolines DA-PMOx could be prepared with a good molecular weight control under relatively high conversion $(<80 \%)$ and alow polydispersity $\left(\mathrm{M}_{\mathrm{w}} / \mathrm{M}_{\mathrm{n}}<1.3\right)$. 
The number average polymerization degree was obtained by SEC analysis and NMR spectroscopy as summarized in Figure 1. A narrow polydispersity ranged from 1.2 to 1.3 and the unimodal SEC traces were detected. The peaks shifted towards higher molecular weights with the same distribution of molecular weight. It wasimportant to notice that polymerization reactions were stopped at about $80 \%$ conversion in order to minimize transfer and control the end-chain functionalities. Whatever the $\mathrm{DP}_{\mathrm{n}}, \mathrm{DP}_{\mathrm{n}}, \mathrm{SEC}$ and $\mathrm{DP}_{\mathrm{n}}, \mathrm{NMR}$, the values were consistent with the theoretical ones. For instance,a target degree of polymerization of 20 actually producedan experimental degree of polymerization of 23.0 and 21.5 . The efficiency of the end functionalization using allylamine was evidenced by NMR spectroscopy.

\begin{tabular}{cccc}
\hline$\overline{\mathrm{DP}_{n}^{\text {th }}}$ & $\overline{\mathrm{DP}_{\mathrm{n}}^{\mathrm{SEC}}}{ }^{\mathrm{N}}$ & $\overline{\mathrm{M}_{\mathrm{n}}^{\mathrm{SEC}}}\left({\left.\mathrm{g} \cdot \mathrm{mol}^{-1}\right)^{*}}^{*} \overline{\mathrm{M}_{\mathrm{w}}} / \overline{\mathrm{M}_{\mathrm{n}}}\right.$ \\
\hline 10 & 9.7 & 900 & $1.2_{2}$ \\
15 & 16.4 & 1500 & $1.2_{1}$ \\
20 & 23.0 & 2000 & $1.2_{6}$ \\
30 & 28.8 & 2500 & $1.3_{1}$ \\
\hline${ }^{*}$ : SEC-RI detector $\left(\mathrm{H}_{2} \mathrm{O} / \mathrm{MeOH}(7 / 3)\right.$-eq PEO).
\end{tabular}

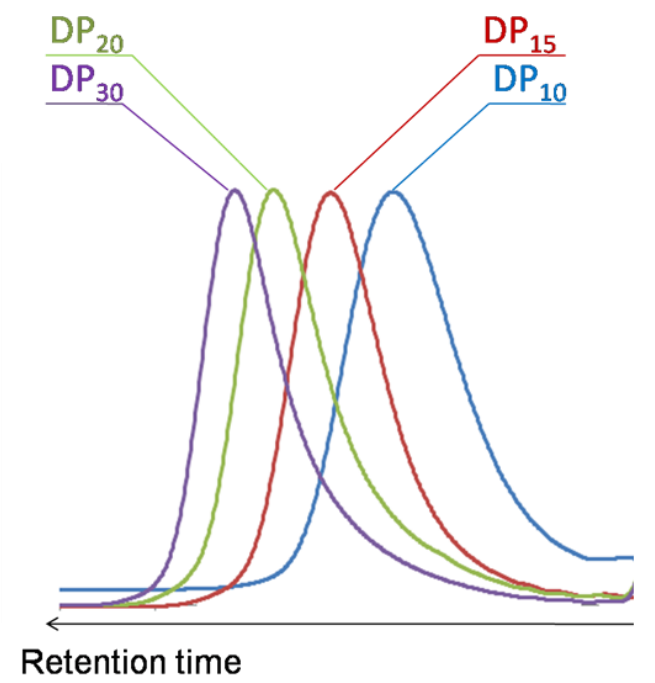

Fig. 1. Molecular weight, polydispersity and SEC trace of DA-PMOxs.

\subsection{Post-functionalization based on double thiol-ene coupling and sol gel condensation}

To date, the synthesis of polyoxazoline bearing alkoxysilane head- and end-groups for further sol-gel condensation used hydrosilylation reaction. Owing to low yield of polyoxazoline modification by hydrosilylation, another synthetic strategy of polyoxazoline postfunctionnalization was explored. One reaction that is emerging as an attractive process is the 
century-old addition of thiols to alkenes, which is currently called thiol-ene coupling (TEC). The TEC reaction has been extensively exploited in polymer chemistry and more specifically in polyoxazoline chemistry on functional monomer or polymer. In our case, the TEC reaction was employed as post-functionalization of polyoxazoline carrying $\alpha, \omega$-unsaturated end groups DAPMOx. The TEC reaction transformed allylic into alkoxysilane end groups. The thiol-ene coupling from DA-PMOx $\left(\mathrm{DP}_{15}\right.$, exp $)$ was realized in excess of mercaptan agent: TEOSi-thiol considering the typical thiol-disulfide interchange reaction [40]. Under free radical condition, the double end group modification (d-TEC) of DA-PMOx into alkoxysilane groups gave Si-PMOxSi (Scheme 1). The conversion was monitored by ${ }^{1} \mathrm{H}$ NMR analysis using the integration of theethylenic signals of DA-PMOx. The ethylenic signals at 5.2 and $5.7 \mathrm{ppm}$ decreased during the TEC reaction. On the other hand, after purification of Si-PMOx-Si, the integration of $\mathrm{CH}_{3}$ signal of $\mathrm{CH}_{3}-\mathrm{CH}_{2}-\mathrm{O}-\mathrm{Si}$ at $1.2 \mathrm{ppm}$ confirmed the reaction of TEOSi-thiol on DA-PMOx (Figure 2). Our first experiments using 0.06 and 0.12 equivalent of $\mathrm{AIBN}$ in $0.1 \mathrm{M}$ yielded in minor amount the target compound: 10 and 15\% conversion, respectively (Supporting Information). This result prompted us to investigate the course of the reaction more thoroughly. An additional amount of AIBN improved the conversion until $45 \%$. Parameter such as the concentration of the reaction mixture was varied. As expected, higher concentration until $0.3 \mathrm{M}$ concentration favored the formation of thioether compound with an optimum $86 \%$ yield. 


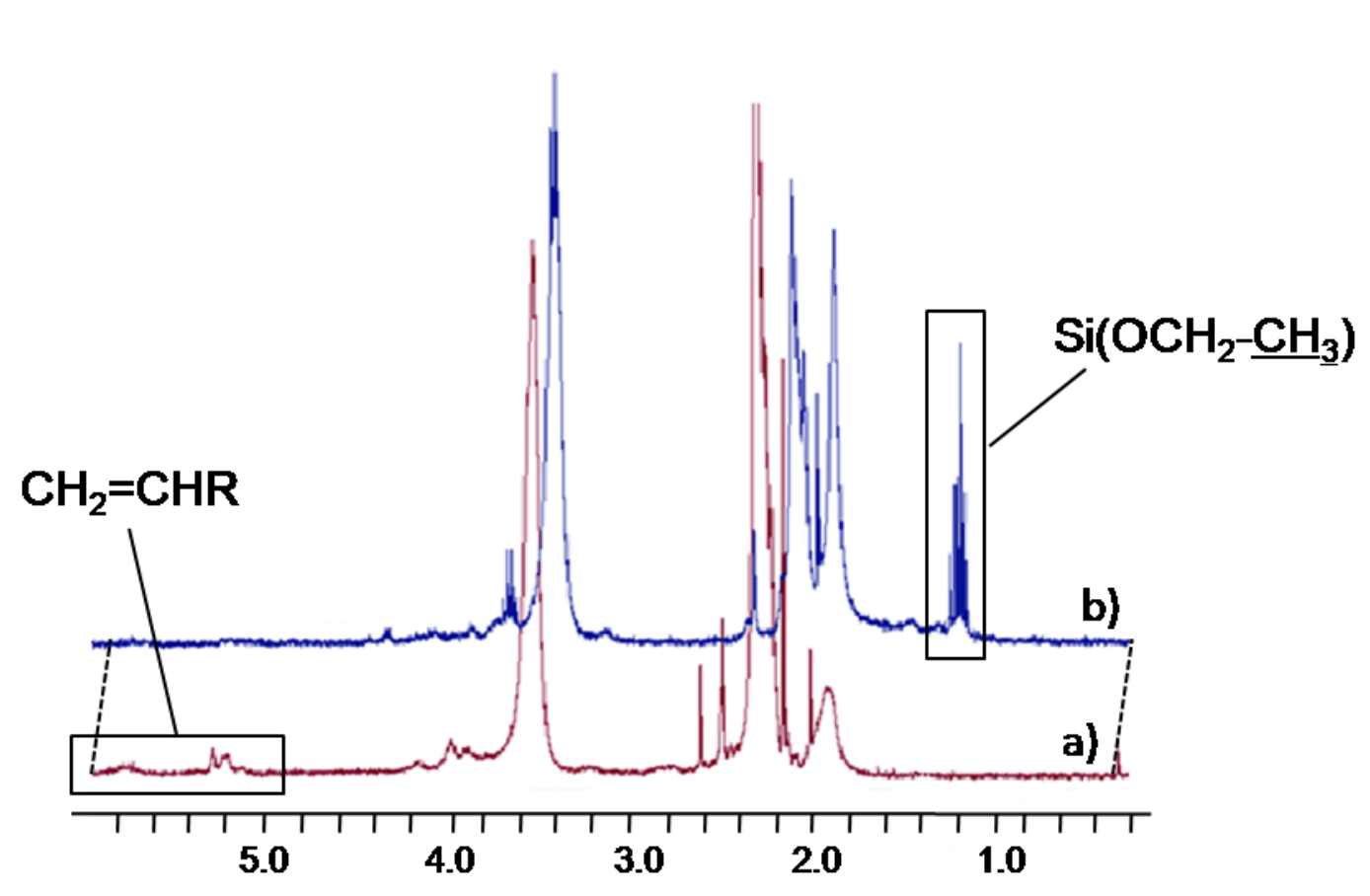

Fig. $2 .{ }^{1} \mathrm{H}$ NMR spectra a) before (DA-PMOx) and b) after thiol-ene reaction (Si-PMOx-Si).

The sol-gel process was carried out through hydrolysis and condensation of Si-PMOx-Si with a mixture of tetraethoxysilane (TEOS) and (3-glycidoxypropyl)trimethoxysilane (GOTMS) (Scheme 2). The latter was used to develop linkage, on one hand with silica network structure using alkoxy groups and on the other hand with polyoxazoline chains through interchain hydrogen bonding [41]. Thanks to the flexibility of PMOx chains the composition of the sol-gel precursor solution was optimized to obtain crack-free film onto substrates. 


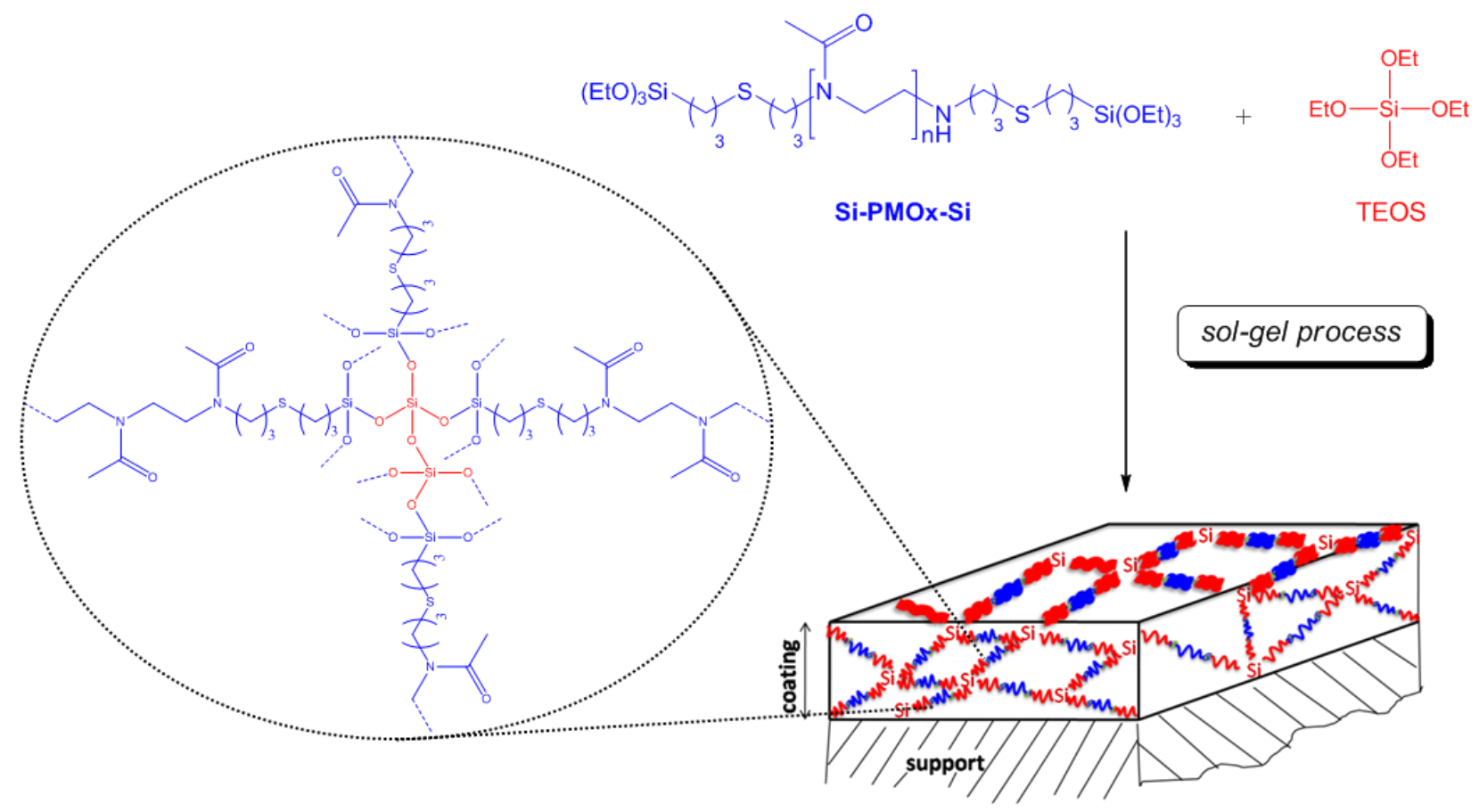

Scheme 2. Elaboration of polyoxazoline coating by sol-gel process.

\subsection{Characterization of polyoxazoline coating on polymer and glass materials}

\subsubsection{Contact angle measurements}

The efficiency of the hybrid sol-gel coating was studied on various polymer supports ranged from PP, CAB, PS, POM to PEI and glass. To get more information on the surface energy of the hydrophilic coating, the contact angle measurements were carried out using probe liquids (water and diiodomethane) as summarized in Table 1. The obtained surface energy values for the raw substrates are in agreement with those previously reported [42]. The experimental values for hybrid coating on substrates are around $63 \pm 2 \mathrm{~mJ} . \mathrm{m}^{-2}$, exceptfor PP. Indeed, the surface energy value is lower as a result of the film cracks. As polyoxazoline is a hydrophilic polymer, [43] it is observed an increase of the surface energy of the substrate related to the hydrophilicity of the coated film. Whatever the substrates, the constant value of the surface energy of the composite materials gave evidence the homogeneity of the hybrid film. The adhesion of hybrid 
polyoxazoline film on the materials was also studied. The value of interfacial energy is an important parameter to determine the adhesion between two components in a composite; it is also a description of the thermodynamic state of the interface [44]. The work of adhesion $\mathrm{W}_{12}$ measures the attraction between two different phases and $\mathrm{W}_{12}=\gamma_{1}+\gamma_{2}-\gamma_{12}$ for the separation process. Therefore the adhesion increases when the interfacial energy decreased. Interfacial energy between substrates (1) and hybrid film (2) in the composite has been determined with:

$$
\gamma_{12}=\gamma_{1}+\gamma_{2}-2 \sqrt{\gamma_{1} \times \gamma_{2}}
$$

Assuming an average value of $63 \mathrm{~mJ} . \mathrm{m}^{-2}$ for $\gamma_{2}$.

The low values of the interfacial energy are in good agreement with the observed adhesion of the polyoxazoline hybrid film coating on the different substrates with surface energy higher than $30 \mathrm{~mJ} \cdot \mathrm{m}^{-2}$.

Table 1.Surface energy of raw and coated substrates.

\begin{tabular}{|c|c|c|c|c|c|c|}
\hline \multirow[b]{2}{*}{ substrate } & \multicolumn{3}{|c|}{ Raw substrate } & \multicolumn{2}{|c|}{ Coated substrate } & \multirow[b]{2}{*}{$\begin{array}{c}\text { interfacial } \\
\text { energy } \\
\gamma_{12} / \mathrm{mJ}^{-2}\end{array}$} \\
\hline & & & $\begin{array}{c}\text { Surface } \\
\text { energy } \\
\gamma_{1} / \mathrm{mJJ}^{-2}\end{array}$ & $\begin{array}{c}\text { contact } \\
\text { angle }\end{array}$ & $\begin{array}{c}\text { Surface } \\
\text { energy } \\
\gamma_{2} / \mathrm{mJJm}^{-2}\end{array}$ & \\
\hline & wate & $\mathrm{CH}_{3} \mathrm{I}$ & & water $\mathrm{CH}_{3}$ & & \\
\hline PP & 88 & 64.5 & 28 & $\begin{array}{ll}63.8 & 45.2\end{array}$ & 43 & 7 \\
\hline POM & 76.7 & 40.3 & 40 & $32.7 \quad 40.9$ & 63 & 2.6 \\
\hline $\mathrm{CAB}$ & 77.4 & 37.1 & 42 & $30.7 \quad 40.9$ & 65 & 2.1 \\
\hline PS & 96.0 & 34.2 & 42 & 29.340 .1 & 65 & 2.1 \\
\hline PEI & 70.6 & 31.8 & 45 & $19.7 \quad 37.1$ & 64 & 1.5 \\
\hline glass & 16.9 & 42.3 & 72 & $\begin{array}{ll}35 & 39.8\end{array}$ & 62 & 0.3 \\
\hline
\end{tabular}

\subsubsection{SEM images}

The top view SEM images of the hybrid silica film deposited on different substrates (Glass, POM, PEI and PP) exhibit a very homogeneous coating with very few defects on the substrates (glass, POM and PEI on Figure 3). The uniformity of the films indicates the 
effectiveness of the coating resulting from the efficient crosslinking of polyoxazoline with alkoxysilane end groups Si-PMOx-Si. On the other hand, the coating on PP substrate shows important cracks that reveal a low adherence of the film as expected the high interfacial energy (Table 1). The coated film thickness, determined from the cross-sectional image (Figure 3), is around $5 \mu \mathrm{m}$.
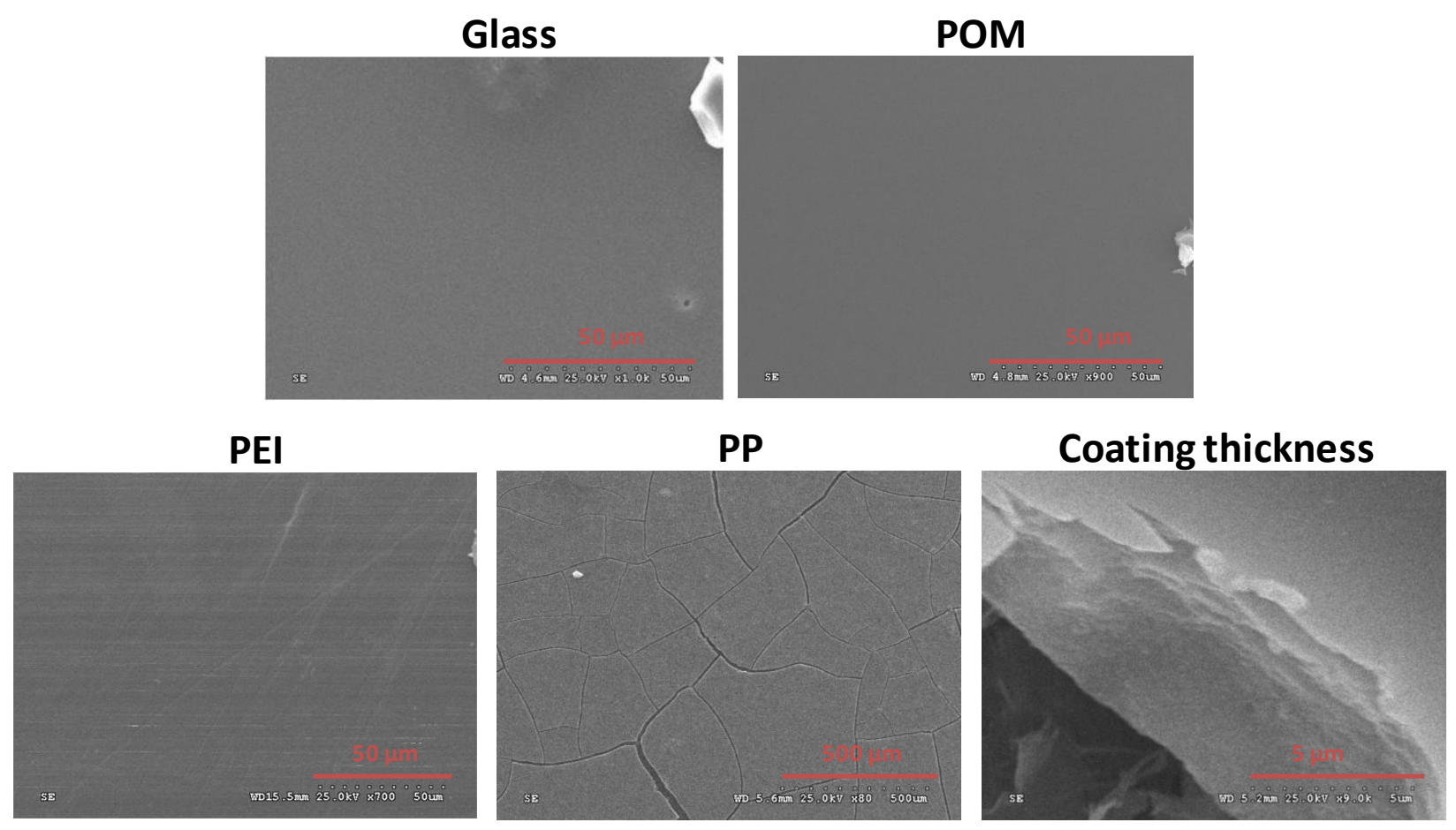

Fig. 3. Top view SEM images and cross sectional image of the hybrid film coated on different substrates: glass, POM, PEI and PP.

\subsubsection{Atomic force microscopy (AFM) images}

AFM images were obtained in tapping mode and phase. The tapping mode allows on polymer to minimize the resulting load force, eliminating the friction forces and avoiding a deformation of the superficial structures by the tip. The surface morphology and roughness, measured from image root mean square $(\mathrm{Rq}$ parameter) were determined in height mode, where 
the root mean square of the amplitude was used as a feedback value to maintain the oscillation amplitude constant. In order to determine the nature of changes that took place in the surface morphology of substrate after hybrid silica coating, AFM was carried out and the results are depicted in Figure 4 for PEI substrate. The observations of other composite materials provide very similar results. No significant alteration of the surface morphology was detected, with a minor reduction in roughness, found to be equal to $0.364 \mathrm{~nm}$ on the raw substrate and $0.268 \mathrm{~nm}$ after coating. The result could be explained by the use of flexible polyoxazoline segments allowing a perfect fit of the surface structure between two crosslink nodes.

Raw PEI

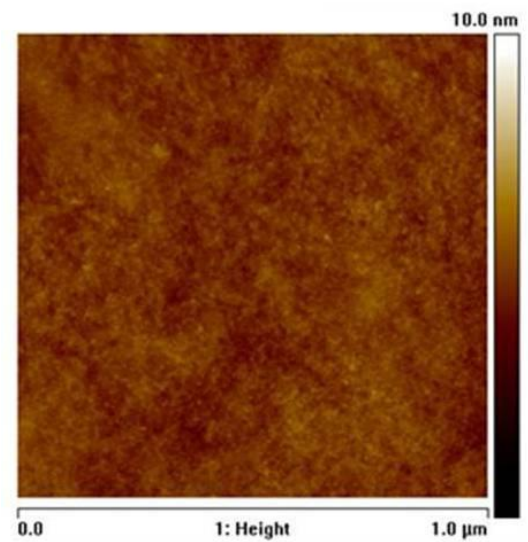

Coated PEI

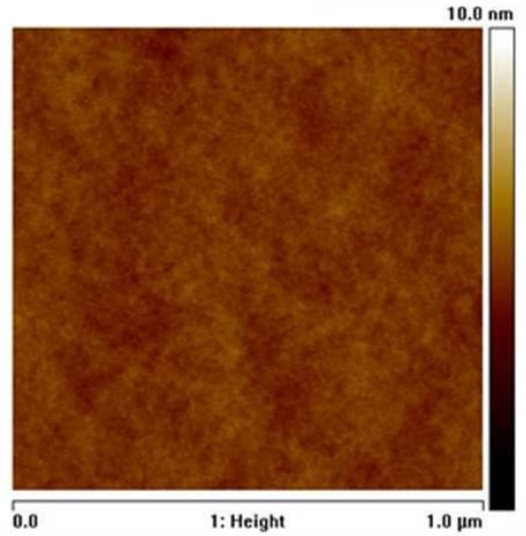

Fig. 4.AFM surface image $(1 * 1 \mu \mathrm{m} 2)$ of uncoated PEI $(\mathrm{Rq}=0.268 \mathrm{~nm}$, on the left $)$ and coated PEI $(\mathrm{Rq}=0.364 \mathrm{~nm}$, on the right) substrate.

\subsubsection{Optical reflectance measurements}

The reflectance measurements show similar spectra for the raw and coated substrates except for the glass (Figure 5) where the reflectivity of the material decreased with the coating. 

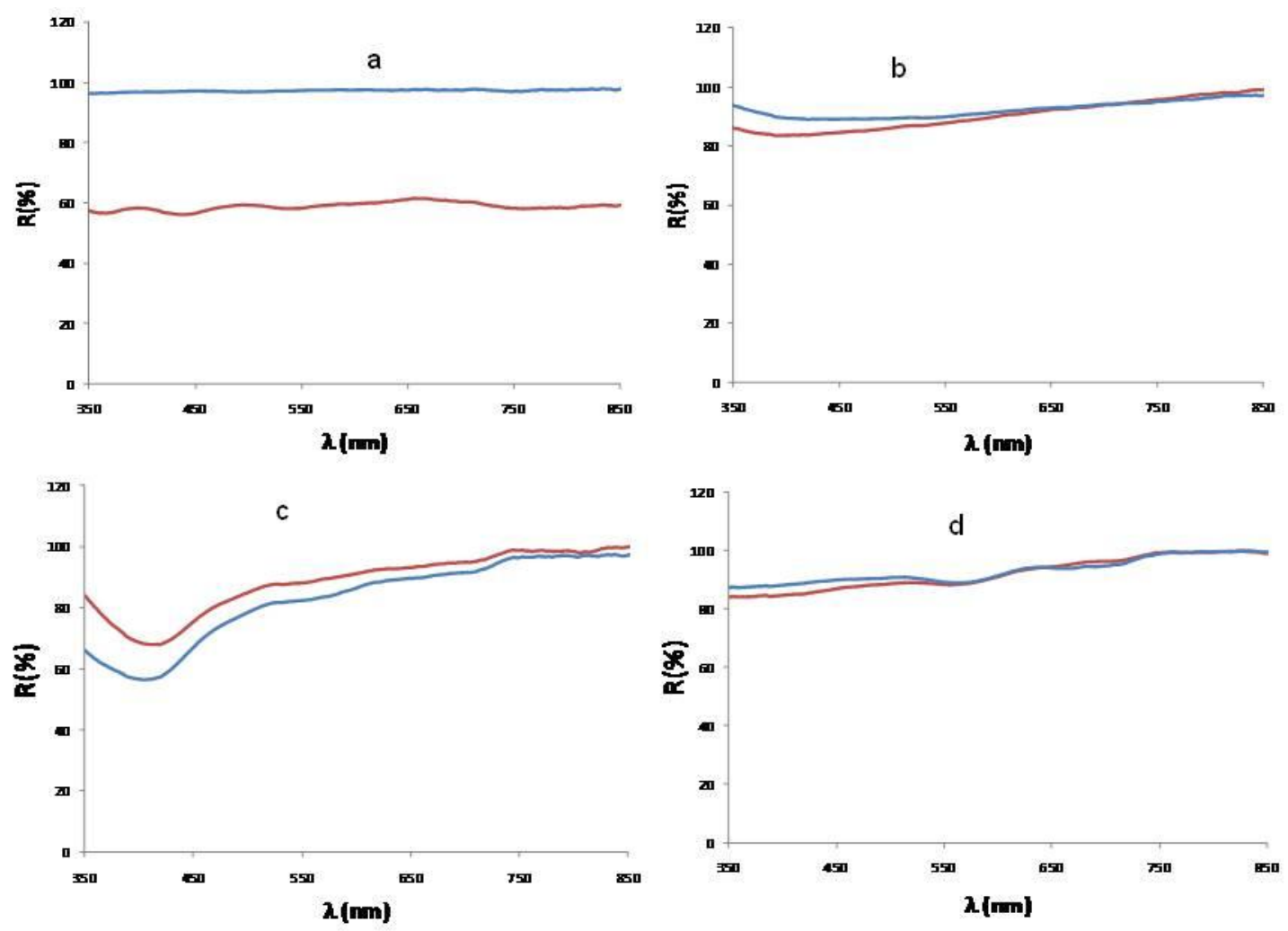

Fig. 5. Reflectance spectra of some raw and coated substrates: a: glass microscope slide, b: POM, c: PEI and d: CAB.

This result indicates that the coated film is efficient to reduce the surface reflection of transparent materials as required for different applications to improve the light transmission [45]. In the case of PEI, the polymer presents a light absorption in the blue region and exhibits a yellow color. The presence of the coated film decreases the absorbance leading to a slight increase of the reflectivity in this region. As a result, the reflectivity measurements indicate that the coated hybrid film does not significantly modify the optical properties of the substrate because of its transparency. 


\section{Conclusions}

Hybrid sol-gel coatings were successfully realized without any preliminary surface activation from PMOx onto various polymer substrates as well as glass support. The crack-free hydrophilic films resulted from a crosslinked network between polyoxazoline flexible chains and inorganic cross-linkers. The $\alpha, \omega$-functionalized polyoxazoline was reached by an original and efficient synthetic route using an one pot head and end-allylation chains followed by the thiol-ene reaction which was a powerful alternative route to silylation for the sol-gel condensation. Finally the reflectivity measurements indicated that the coated hybrid films do not significantly modify the optical properties of the substrates and no defect was detected in AFM and SEM images of the coatings. 


\section{References}

1 a) J.D. Mackenzie, E. Bescher J. Sol-Gel Sci. Technol., 27 (2003), 7-14; b) L. Buruaga, A. Gonzalez, J. J. Iruin, J. Mat. Sci., 44 (2009) 3186-3191.

2.T. Gururaj, R. Subasri, K.R.C. soma Raju, G. Padmanabham, Applied Surfaces Science, 237 (2011) $4360-4364$

3.K. C. Song, J. K. Park, H. U. S. H. Kang and J. Kim, Sol-Gel Sci. Technol., 27, (2003) 53-59.

4.L. Buruaga, A. Gonzalez and J. J. Iruin, J. Mat. Sci., 44 (2009) 3186-3191.

5.W. L. Bunnelle, R. Hume and K. C. Knutson, US Patent 5,459,184, (1985).

6.N. Adams and U. S. Schubert, Adv. Drug Deliv. Rev., 59, 15, (2007) 1504-1520.

7.P. Farkas, J. Korcova and S. Bystricky, Eur. J. Med. Chem., 45 (2010) 795-799.

8.A. Mecke, C. Dittrich and W. Meier, Soft Matter., 2, (2006) 751-759.

9.S. Zalipsky, C. B. Hansen, Oaks J. M. and T. M Allen, J. Pharm. Sc., 85, (1996) 133-137.

10.K. Aoi, M. Okada, Prog. Polym. Sci. 21, (1996) 151-208.

11.R. Hoogenboom, Macromol. Chem. Phys., 208, (2007) 18.

12.H. Schlaad, Diehl C., A. Gress, M. Meyer, A. L. Demirel, Y. Nur and A. Bertin, Macromol. Rapid Commun., 31, (2010) 511-525.

13.P. Broz, S. M. Benito, C. L. Saw, P. Burger, H. Heider, M. Pfisterer, S. Marsch, W. Meier and P. Hunziker, J. Control. Release, 102, (2005) 475-488.

14.C. Giardi, V. Lapinte, C. Charnay and J. J. Robin, React. Funct. Polym., 69, (2009) 643-649.

15.B. Guillerm, S. Monge, V. Lapinte and J. J. Robin, Macromolecules, 43, (2010) 5964-5970.

16.C. Giardi, V. Lapinte, F. Nielloud, J. M. Devoisselle and J. J. Robin J. Polym. Sc.: Part A: Polym. Chem., 48, (2010) 4027-4035.

17.T. Loontjens and L. Rique-Lurbet, Design. Monomers Polym., 2, (1999) 217-229.

18.J. H. Lee, Y. C. An, D. S. Choi, M. J. Lee, K. M. Kim, J. H. Lim, Macromol. Symp. 249-250, (2007) 307-311.

19.R. Konradi, B. Pidhatika, A. Muhlebach and M. Textor, Langmuir, 24, (2008) 613-616.

20.T. Ogoshi and Y. Chujo, Polymer, 47, (2006) 4036-4041.

21.T. Saegusa and Y. Chujo, Makromol. Chem. Macromol. Symp., 64, (1992) 1-9.

22.Y. Chujo, S. Kure, H. Matsuki and T. Saegusa, Proc. Japan Acad., Ser. B, (1994) 138-142. 
23.Y. Chujo, Ihara E., H. Ihara and T. Saegusa, Polymer Bull., 19, (1988) 435-440.

24.G. Cai and M. H. Litt, J. Polym. Sc.: Part A: Polym. Chem., 30, (1992) 649-657.

25.G. Cai and M. H. Litt, J. Polym. Sc.: Part A: Polym. Chem., 30, (1992) 659-669.

26.Y. Chujo, E. Ihara, S. Kure, K. Suzuki and T. Saegusa, Makromol. Chem. Macromol. Symp., 42, (1991) 303-312.

27.Y. Chujo, E. Ihara, S. Kure and T. Saegusa, Macromolecules, 26, (1993) 5681-5686.

28.A. Fortig, R. Jordan, K. Graf, G. Schiavon, O. Purrucker and M. Tanaka, Macromol. Symp., 210, (2004) 329-338.

29.Y. Chujo, K. Sada, T. Kawasaki, E. Ihara, and T. Saegusa, Polymer Bull., 31, (1993) 311-316.

30.T. Loontjesand L. Rique-Lurbet, Des. Monomers Polym., 2, 3, (1999) 217-229.

31.C. E. Hoyle, T. Y. Lee and T. Roper, J. Polym. Sc. Part A: Polym. Chem., 42, (2004) 5301-5338.

32.P. Lucas, E. Fleury, J. F. Estur, V. Lapinte and J. J. Robin, Macromol. Chem. Phys., 210, (2009) 1933-1941.

33.J. A. Carioscia, H. Lu, J. W. Stanbury and C. N. Bowman, Dent. Mater., 21, (2005) 1137-1143.

34.Diehl C. and H. Schlaad, Macromol. Biosci., 9, (2009) 157-161.

35.M. A. Cortez and S. M. Grayson, Macromolecules, 43, (2010) 4081-4090.

36.E. Del Rio, G. Lligadas, J. C. Ronda, M. Galia, V. Cadiz, J. Polym. Sc.: Part A: Polym. Chem., 49, (2011) 30693079.

37.S. Cesana, A. Kurek, M. A. Baur, J. Auernheimer and O. Nuyken, Macromol. Rapid Commun., 28, (2007) 608615.

38.A. Gress, A. Völkel and H. Schlaad, Macromolecules, 40, (2007) 7928-7933.

39.D. Perrin, Purification of laboratory chemicals. New York: Pergamon press, 1980.

40.B. M. Kiran and N. Jayaraman, Macromolecules, 42 (2009) 7353-7359.

41.H. Zou, S. Wu and J. Shen, Chem. Rev., 108, (2008) 3893-3957.

42.Polymer Handbook; J. Brandrup, E. H. Immergut and E. A. Grulke, Eds.; John Wiley \& Sons: New York, 1999.

43.K. Rupert, B. Pidhatika, A. Muhlebach and M. Textor Langmuir, 24, (2008)613-616.

44.H. Yin and G. M. Chow, J. Biomed. Mat. Res. Part A, (2008) 331-341.

45.M. C. Bautista, A. Morales, Sol. Energy Mater. Sol. Cells 80, (2003) 217-225. 